\title{
Article \\ Comprehensive Food System Planning for Urban Food Security in Nanjing, China
}

\author{
Taiyang Zhong ${ }^{1}$, Zhenzhong $\mathrm{Si}^{2}$, Steffanie Scott ${ }^{3}$, Jonathan Crush ${ }^{2,4, * \mathbb{D}}$, Kui Yang ${ }^{1}$ and Xianjin Huang ${ }^{1}$ \\ 1 School of Geography and Ocean Science, Nanjing University, Nanjing 210093, China; zty@nju.edu.cn (T.Z.); \\ mg1827047@smail.nju.edu.cn (K.Y.); hxj369@nju.edu.cn (X.H.) \\ 2 Balsillie School of International Affairs, Waterloo, ON N2L 6C2, Canada; zsi@wlu.ca \\ 3 Department of Geography and Environmental Management, University of Waterloo, \\ Waterloo, ON N2L 3G1, Canada; sdscott@uwaterloo.ca \\ 4 Department of Geography, Environment and Tourism, University of the Western Cape, \\ Cape Town 7535, South Africa \\ * Correspondence: jcrush@balsillieschool.ca
}

Citation: Zhong, T.; Si, Z.; Scott, S.; Crush, J.; Yang, K.; Huang, X.

Comprehensive Food System

Planning for Urban Food Security in Nanjing, China. Land 2021, 10, 1090. https://doi.org/10.3390/

land 10101090

Academic Editors: Alessandro Bonifazi and Carlo Rega

Received: 23 August 2021

Accepted: 8 October 2021

Published: 15 October 2021

Publisher's Note: MDPI stays neutral with regard to jurisdictional claims in published maps and institutional affiliations.

Copyright: (C) 2021 by the authors. Licensee MDPI, Basel, Switzerland. This article is an open access article distributed under the terms and conditions of the Creative Commons Attribution (CC BY) license (https:// creativecommons.org/licenses/by/ $4.0 /)$.
Abstract: Food system planning is important to achieve the goal of "zero hunger" in the UN's 2030 Agenda for Sustainable Development (UN, 2016). However, discussion about comprehensive planning for food security is scarce and little is known about the situation in Chinese cities. To narrow this gap, this study collected and analyzed four medium-term plans and two annual plans for the "vegetable basket project" in Nanjing, China. This study examines the strategies for urban food security in Nanjing to shed light on how the city developed a comprehensive approach to food system planning over the past three decades. The evolution of incremental food system planning in Nanjing provides valuable lessons for other cities facing food security challenges and shortages of financial resources. Reducing food insecurity is an ongoing challenge for the city governments in the Global South and comprehensive planning is a useful tool for addressing the challenge of urban food insecurity.

Keywords: zero hunger; food system; food planning; food security; Nanjing; China

\section{Introduction}

Until recently, scholars and practitioners were bemoaning the absence of the food system from urban planning in the Global North [1-3]. One review of urban planning in the US for example, concluded that the food system was a "stranger" to urban planning, notable by its absence from practice, research, and education [4]. In similar vein, Morgan pointed to what he called the "puzzling omission" of the urban food system from city planning in the Global North, but concluded on a more optimistic note that the reasons are "now a matter of historical interest only because, for the foreseeable future, food planning looks set to become an important and legitimate part of the planning agenda in developed and developing countries alike" [1] (p. 341). This may well be an accurate depiction of the integration of food systems into urban planning in the well-resourced governance of "smart cities" in the Global North [5-9]. The more pertinent question here is whether food system planning has also become "an important and legitimate" part of the planning agenda in countries of the Global South [10]. Although greater attention has recently been paid to food system planning through initiatives such as the New Urban Agenda [11], the Milan Food Pact [12] and the FAO's City-Region Food System (CRFS) program [13], it is notably absent from Sustainable Development Goal 11 on Sustainable Cities [14]. These new approaches have also been criticized for their uncritical promotion of localization and urban agriculture and their Northern bias [11,15].

Reviewing the evidence from cities across the Global South, Haysom (2020: 373) concludes that "Northern style pluralistic food-governance structures are inappropriate 
and would not result in the necessary change in urban food-system outcomes" [10] (p. 373). Several reasons can be advanced for why integration of the food system has generally not been a feature of urban planning in most cities across the Global South. First, food insecurity is still largely perceived as a rural and agricultural rather than urban problem, a view reinforced by international organizations such as the FAO and IFAD, as well as western philanthropic organizations such as Rockefeller and Gates [16,17]. Second, consistent with the notion that food insecurity can be mitigated through increased food production, there has been a single-minded focus on promoting urban agriculture as the panacea for food insecurity in cities [18-20]. Third, there is a fundamental deficit of information about the nature of food systems and the drivers and prevalence of food insecurity at the urban scale [21]. Finally, food security is primarily seen as a responsibility of national not local government in most countries [22]. As a result, city governments lack the mandate, institutions, knowledge and resources to integrate food systems and food security into urban development planning. As Crush et al. note, however, "failure to address the development challenges of urban food insecurity, rising food prices, and low incomes will have serious unintended consequences for the Global South and will undermine efforts to achieve a sustainable urban future" [23] (p. 1).

The Chinese case is of particular interest and relevance because it does not fit easily within these narratives of the past exclusion and future incorporation of the urban food system into city planning, nor is it indebted to governance models developed in and promoted by the Global North or UN agencies such as the FAO. Morgan's assertion about the puzzling omission of urban food systems in city planning prior to the second decade of this century omits the fact that Chinese planners at national, provincial and city level have been grappling with the need to integrate food systems thinking and the food security of the urban population into urban development strategies since the 1980s [2]. The Chinese experience is of more than "historical interest", since it has clearly played a significant role in ensuring food security under conditions of rapid urbanization and continues to be adapted and refined through to the present. There is certainly no a priori reason why the planning urban food system models developed by and for western cities with a long history of urbanization should be more appropriate for the newly urbanizing Global South than those of a country, like China, that is experiencing a similar urbanization trajectory.

This paper first provides a contextual overview of urbanization in China and the early and associated development of urban food system planning designed to achieve food security for all. This provides a context for a discussion of the emergence of Chinese urban food system planning and governance at the local level, a strategy we refer to as comprehensive food system planning, which reaches well beyond the food availability focus of existing Global South strategies to consider other pillars of food security, including access, utilization and stability. To provide insights into Chinese local food system governance, the paper focuses on the case study city of Nanjing in Jiangsu Province, a city of eight million people that has very low levels of food insecurity despite having grown extremely rapidly in recent decades.

The literature on food security in China has traditionally interpreted the main goal of food security planning as self-sufficiency of grains at the national level [24,25]. However, food security is seen by the central government as a multi-scalar issue involving sub-national territorial entities (provinces, prefectures and cities) and levels of governance (central, provincial and municipal/mayoral). The complex challenges of ensuring food security amidst conditions of rapid urbanization have led to incremental policy shifts at the local level, where municipal governments have developed and implemented comprehensive food system plans aimed at ensuring that all four pillars of food security-availability, access, utilization and stability - are guaranteed for the urban population [26]. This paper aims to trace how comprehensive food system planning was incrementally developed in the city of Nanjing over the past three decades in order to try and address urban household food security through enhancing food availability, accessibility, utilization and multilevel stability of the food supply. Using the four pillars of food security as a conceptual 
framework, the paper takes a food system perspective to analyze city government policies and plans. The main objective of the paper is not to evaluate the effectiveness of specific policies in achieving their stated goals, but rather to examine how food security planning changed over time and became more comprehensive and systemic in its thinking and goals. However, the paper does triangulate these goals with fieldwork data from our city-wide household food security survey in Nanjing to assess whether the planning process achieved its overall goal of ensuring food security for all. The conclusion of the paper reflects on the implications of the case study for urban food system planning in the Global South more generally.

\section{Urbanization and Food Security in China}

The UN 2030 Sustainable Development Agenda's Sustainable Development Goal (SDG) No. 2 ("Zero Hunger") aims to end hunger, all forms of malnutrition, and moderate and severe food insecurity globally by 2030 [27]. China is one country that has already made significant progress in reducing hunger and food insecurity in recent decades. The 2015 Millennium Development Goals Report, for example, noted that "China alone accounts for almost two thirds of the total reduction in the number of undernourished people in the developing regions since 1990" [28] (p. 21). The total number of undernourished people in China fell by over half from 289 to 125 million between 1990-92 and 2016-2017 [29,30]. FAO's latest report shows that the Prevalence of Undernourishment (PoU) in the population has been below 2.5\% since 2017 (down from 23.9\% in 1990) [31]. China has therefore made considerable progress in resolving what Du and King refer to as the "puzzle" of reducing food insecurity under conditions of rapid urbanization [32].

Studies of China's food security achievements have tended to focus on issues of agricultural production and food supply, on how food is made available through state-led reform of the agricultural sector and strategic food importation from global markets [33-35]. Yet, rapid urbanization has been an ongoing challenge for China to ensure a sufficient food supply $[25,36,37]$. Urban expansion puts pressure on the food supply through encroaching on fertile farmland and increasing food demand and thus has threatened regional food security $[38,39]$. In response to farmland loss, intensification of farmland use has been the main strategy to increase food production in China [39]. These measures are able to ensure the availability of food, but they come at environmental costs that have led to challenges for land use policy [40]. The emerging consensus is that China has to find ways to increase food production to meet increasing food demand with a shrinking farmland area and reducing adverse environmental impacts [41,42]. Moreover, there is a growing concern about food safety among consumers due to pesticide and veterinary drug residues and heavy metal pollution in the agricultural sector [43-46].

The literature's focus on food production, food safety, and the negative impact of urbanization on farmland has meant that other urban aspects of the resolution of China's food security "puzzle" have been underexplored. In particular, insufficient attention has been given to how China has approached the challenge of ensuring food security for the residents of cities in a context of rapid urbanization, which has seen the proportion of the population living in urban areas increase from less than $10 \%$ in 1950 to nearly $60 \%$ in 2020 (Figure 1).

Rapid urbanization in many parts of the world has led to a dramatic increase in urban poverty and food insecurity, exemplified by the large informal settlements that ring many cities and rates of unemployment that approach $50 \%$ in some cities [47-50]. Unlike many other developing countries that have experienced high levels of food insecurity among urbanizing populations, many cities in China have attained a high level of food security through a deliberate strategy of comprehensive food security planning. While China's unparalleled economic growth has done much to reduce poverty and alleviate food insecurity challenges at the national level, the challenges of ensuring the food security of new urban populations necessitated the development and adoption of new national and local food policies and governance structures. While food security has been and will continue to 
be a challenge for Chinese cities, many local governments have gradually developed and integrated comprehensive food security policies into city planning [51], although the trajectory and substance of policy development has varied between different regions and cities. Planning for food security has not been particularly strong or effective in other countries undergoing rapid urbanization which makes the Chinese case of particular interest and relevance in other jurisdictions, particularly at the local government level.

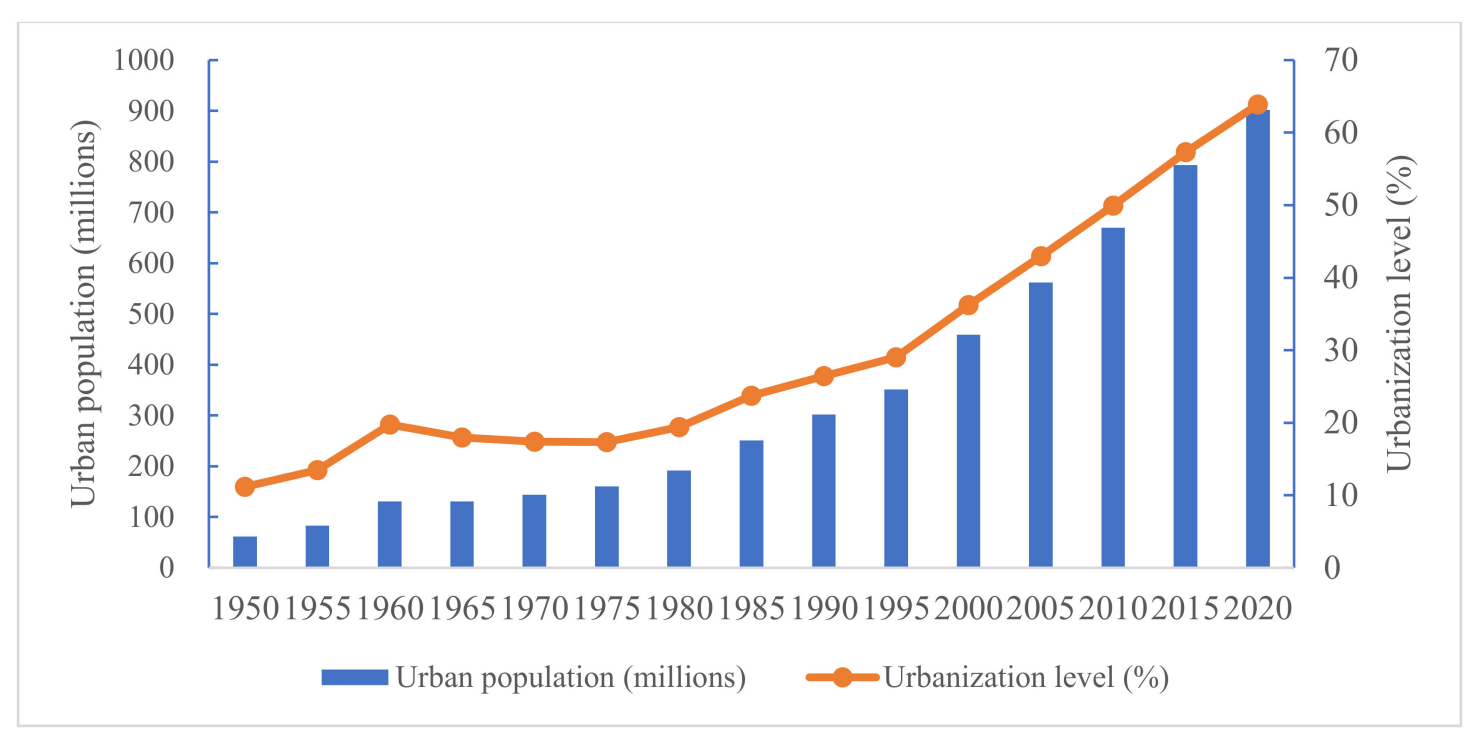

Figure 1. Urbanization in China, 1950-2020 (Source: National Bureau of Statistics).

\section{The Development of Comprehensive Food System Planning in Nanjing}

In the late 1990s, scholars pointed out that the food system had been a "stranger to the planning field" [52]. With growing recognition of food's role in urban development, the planning community has increasingly engaged with food system planning in the Global North $[2,53]$. Although food system planning is an indispensable tool for achieving food security [54], discussion of "comprehensive planning" for food security is rare in the Global South and little scholarly attention has been paid to the process in Chinese cities. Comprehensive planning for food security in China generally refers to a planning strategy developed through collaboration among multiple levels of governance and public and private interests and adopting cross-sectoral strategies (such as, farmland planning, urban land use planning, food reserves system building, and food outlet planning) to achieve the four main goals of food security (i.e., availability, accessibility, utilization, and stability for all).

\subsection{Incremental Implementation}

There are two top-down levels of governmental responsibility for the implementation of food security planning across China. First, the "rice bag" system implemented since 1995 tasks the country's provincial governors with responsibility for the grain cereal supply and for pricing in the province [37]. Second, the "vegetable basket" system implemented since 1988 tasks city mayors with responsibility for the supply of non-grain food in their city. Here, we focus on the implementation of the vegetable basket system by the Nanjing Mayor and Municipal Government.

Nanjing was one of the first Chinese cities to create an implementation plan for the vegetable basket project [55]. Over the ensuing 30 years, the Municipal Government developed and refined its plans, always with the stated goal of making fresh and healthy food economically and physically accessible to the growing population of the city. This gradualist approach is evident from an analysis of the city's four medium-term plans, including plans for 1989-1992, 1993-1997, 1996-2000 and 2008-2012, and two annual plans (2017 
and 2018) [56-59]. The evolution of the planning process demonstrates an iterative policy approach and the incremental incorporation of all four pillars or dimensions of food security: availability, accessibility, utilization and stability [26]. These dimensions are necessarily sequential in policy-making when there is extensive food insecurity and a very limited state budget to tackle them simultaneously [60]. Nanjing opted for a planning strategy initially focused on food production (availability), and then gradually evolved that into a more comprehensive plan encompassing the whole food supply chain (production, storage and reserve, processing, distribution, retailing and consumption) based on all four dimensions of food security (Figure 2). Thus, Nanjing's first plan for the "vegetable basket project" focused on the production of non-grain food, while its second plan placed emphasis on food wholesale market development. The third plan added the dimension of food retailing market development, and the fourth plan increased in scope to include food safety and food reserves. The 2017 and 2018 plans further involved consumer price subsidies. These plans for Nanjing embody an incremental overlay of food security dimensions over the past 30 years, which reflects a gradualist approach of food security planning. Sections 3.2-3.5 examine in greater detail how the gradualist approach of food security planning in Nanjing unfolded through gradually incorporating the four dimensions of food security (availability, access, utilization and stability) into food system planning.

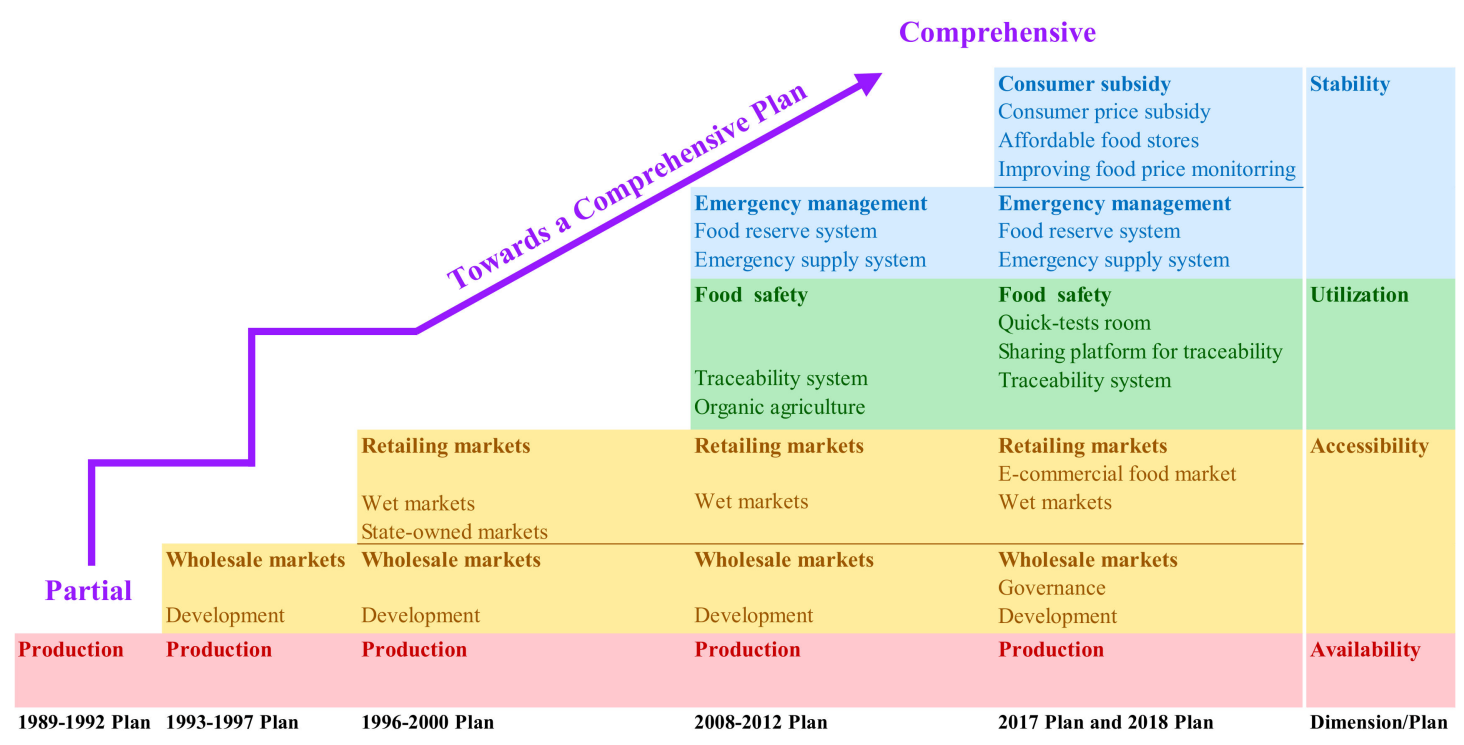

Figure 2. Incremental development of food system planning in Nanjing. (Source: The authors).

The planning process brought together sectoral planning departments, facilitating cross-level and cross-sector negotiation, and reaching agreements regarding responsibilities and inputs. The number of governmental units involved in Nanjing's vegetable basket project increased from seven in 1988 to more than 20 in 2019. The sectoral plans (for farmland protection, agriculture, commerce and urban planning) are all related to some degree to food security. To coordinate planning and implementation, the municipal government established a lead team for the vegetable basket project in the early 1990s. Members of the team include the city vice mayor and leaders of various government departments. The lead team appoints its own office staff and designates a lead unit. Government units such as the Planning Commission, Finance Bureau, and Commerce Bureau have all played the role of lead unit at different times. In 2010, the municipal government released a plan for agricultural production for the period 2010 to 2020 and a plan for commerce network for the period 2016 to 2030, which includes the development of food wholesale markets and wet markets. In 2016, the Nanjing Municipal Development and Reform Commission also developed a vegetable basket development plan for the period 2016 to 2020, and is in the process of developing its 2021-2025 vegetable basket development plan. 
Besides the lead team mechanism, outside assessment of city mayors' performance on the vegetable basket project spurred the Nanjing mayor to pay close attention to the coordination of planning and implementation. This assessment process has been implemented since the mid-1990s and was strengthened by the central government in 2017 when the State Council began to assess the performance of 36 large cities including Nanjing. A policy titled "Rules for Implementation of the Measures for Evaluating the Performance of City Mayors Responsible for Non-grain Food Supply" was issued by central government in 2017, which specified the performance assessment indicators and data collection methods [55]. Performance indicators include the productivity of various kinds of food in the jurisdiction, the number and capacity of food markets, the governance of food safety and food quality, the management system of vegetable basket project, and residents' level of satisfaction.

\subsection{Ensuring Food Availability}

Nanjing's initial vegetable basket plan (1989-1992) centered on local food production by specifying production targets and establishing a self-sufficiency ratio of meat, vegetable, milk, egg, and aquatic products. The plan incorporated a package of policies to support production of fresh produce, including credit support, subsidies, reduced tax and fees, minimum support prices, and a new public fund to support implementation of the project. The priority given to boosting local food production has been continuously highlighted in all of the subsequent plans (Figure 3). Policies for supporting greenhouse farming in suburban areas were seen as a particularly important instrument for boosting local food production [61]. To increase the yield and stability of vegetable production, Nanjing made efforts to develop greenhouse vegetable planting in the peri-urban area. Responsibility for meeting greenhouse vegetable planting targets was handed down from municipal to county-level, and then to township-level governments. The development of greenhouse cultivation, particularly the construction of new greenhouses, was subsidized by the municipal government, which also provided agricultural extension services and training to both local farmers and migrant [61]. Some township-level governments facilitated the renting of farmland to increase greenhouse vegetable production [61]. The third plan (1996-2000) proposed to increase the area of greenhouse for vegetable farming, and the fourth plan (2008-2012) proposed to build about 6667 ha of new greenhouse vegetable planting. The implementation of these plans has led to a regular increase of the area devoted to greenhouse cultivation. Data from remote-sensing images shows that the area of greenhouse farming increased from about 24 ha in 1995 to 150 ha in 1999, to 3930 ha in 2010, and to 7587 ha in 2014 [61]. Our remote-sensing data shows that the area of greenhouse farming was 8237 ha in 2019 (Figure 3). The ratio of sown greenhouse vegetables to total sown area of vegetables increased from $4.3 \%$ in 2006 to $10.9 \%$ in 2016 .

The support of greenhouse farming in peri-urban Nanjing was reinforced by farmland protection policies to restrict urban sprawl and maintain a certain level of farmland through land consolidation and reclamation [62]. In areas where villagers had moved to towns, some rural construction land formerly used for village settlement was reclaimed for vegetable greenhouses. However, Nanjing failed to meet the goal of no net loss of farmland in its land use plan (1996-2010). Data from the Chinese Academy of Sciences shows that the total area of arable land decreased from 435,014 ha in 1990 to 332,489 ha in 2020 (a 24\% reduction), while the area of relatively high-quality paddy field decreased by about $21 \%$ from 304,187 ha to 241,494 ha. Despite the declining area under cultivation, the actual production of non-grain food has significantly increased in Nanjing [37]. Vegetable production increased from 893.4 thousand tones in 1990 to 2799.1 thousand tones in 2019 [63]. The production of fruit and fishery products also increased, although grain production significantly declined from 1732.6 thousand tones in 1990 to 965.6 thousand tones in 2019, necessitating increased imports to the city from other regions [63]. 


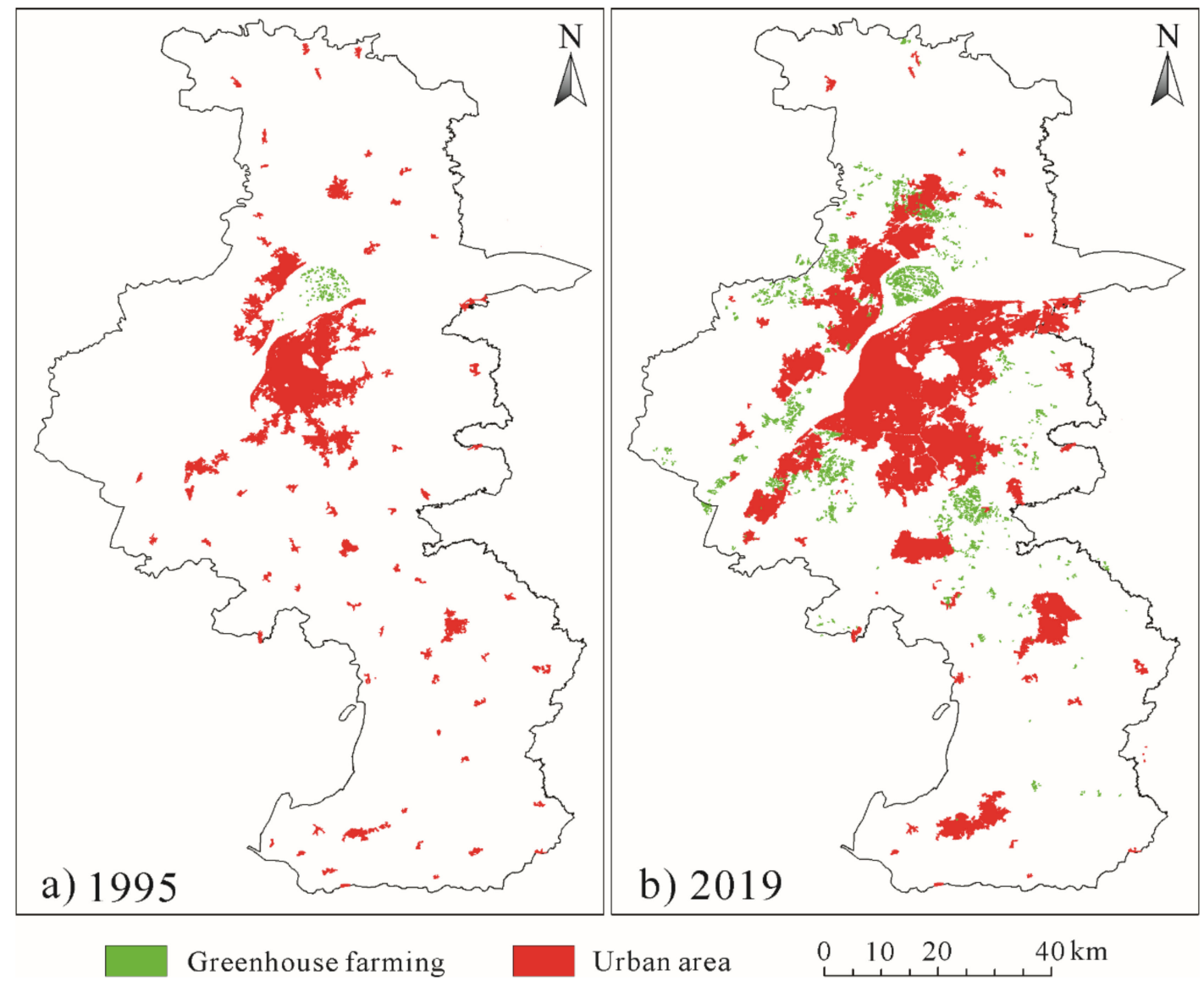

Figure 3. Greenhouse farming expansion in Nanjing from 1995 to 2019. (Source: Adapted from Zhong et al. (2020)).

\subsection{Enhancing Food Accessibility}

Most residents of Nanjing rely on fresh food purchase from three main sources: supermarkets, wet markets, and small food stores (Figure 4). These retail outlets ship in food from city wholesale markets or direct from suppliers in supply chains connected to farms [64]. Our city-wide urban household food security survey in 2015 found that $93 \%$ of households bought food from wet markets and $75 \%$ did so almost daily. The corresponding patronage patterns for supermarkets were $87 \%$ and $17 \%$. About $30 \%$ of households bought food from small shops [65].

Food accessibility policies and planning in Nanjing have focused primarily on the governance of food markets. The first strategy has been the upgrading of old and the establishment of new food markets, including wet markets and wholesale markets. The initial proposal involved the development of four wholesale markets: one each for vegetables, aquatic products, poultry, and pork. The 2008-2012 Nanjing Plan proposed the development of 30 wet markets and two new wholesale markets for grain and non-grain foods, respectively. The Zhongcai Wholesale Market for non-grain food was built and operationalized in 2009. This is the biggest food wholesale market in Nanjing and hosts more than 4000 food wholesaling merchants [66]. Xingang Cereal \& Oil Wholesale Market opened in 2014. The number of wet markets in the city increased to 385 in 2019 [66]. The latest plans turn to supporting management and improvements to the wholesale markets, including developing food traceability systems, food testing labs, and e-commerce. 


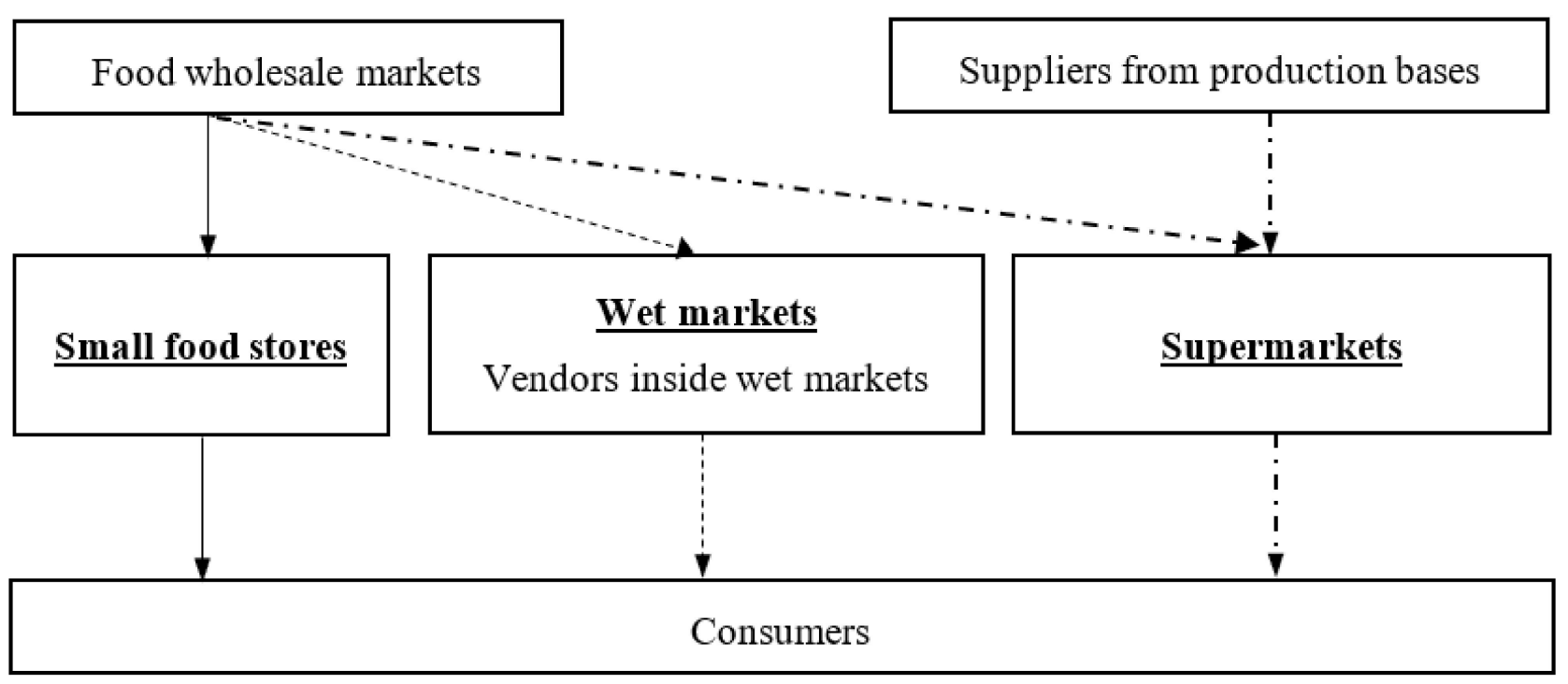

$\longrightarrow$ Food flow via small stores $\quad \cdots$ Food flow wet markets $\quad \cdots \rightarrow$ Food flow supermarkets

Figure 4. Households' food sources in Nanjing.

The second strategy aimed at improving food accessibility has been to increase the overall density of food outlets. From 1993, it became mandatory to build a wet market of at least $500 \mathrm{~m}$ square meters to serve any residential neighborhood with a population of 10-15,000. Since 2011, real-estate developers have been required to build a new wet market whenever a residential area is developed and to transfer the new wet market's ownership to the district-level (county-level) government [66]. For instance, the wet market in Figure 5 was established in 2015 with an area of 1200 square meters and serves a neighborhood of about 3200 households and more than 15,000 residents. Both the 2017 and 2018 Plans went further and proposed that each housing complex in the city should have physical access to five different "vegetable baskets" or food outlets. These included Basket 1: wet markets; Basket 2: fresh produce zones in supermarkets; Basket 3: 'favorableprice' food shops for fresh produce at subsidized prices; Basket 4: e-commerce lockers for online food deliveries; and Basket 5: self-pick-up stores (Figure 5). This policy was also designed to maximize access to fresh produce throughout the day, as the "baskets" generally have different business hours. These policies have ensured the development of food retailing outlets specified in food security plans and improved access to food such as fresh meat, vegetables and fruit. This is reflected in the fact that about $80 \%$ of surveyed households are less than two kilometers away from the nearest wet market or supermarket [65]. Over $90 \%$ of surveyed households bought pork, vegetables and fruit within walking distance. In residential neighborhoods still without ready access to markets, the municipal government has supported the establishment of small fresh food shops such as Basket 3 shown in Figure 5.

The third strategy for addressing accessibility relates more to economic than physical access by addressing issues of food affordability. The 2017 and 2018 Plans, for example, explicitly mention stabilizing food prices. Proposed measures include strengthening food price monitoring, cracking down on illegal pricing, and developing affordable food shops. Other indirect price stabilization plans include subsidizing food production, food transportation, and food retailing. The recent annual plans propose government income subsidies to low-income households when the monthly increase of food prices is over the threshold of $6 \%$ or the monthly consumer price index rises by more than $3 \%$. The development and upgrading of wet markets have also been subsidized by the municipal government [66]. A public-private hybrid governance model is used to regulate wet markets [66]. Competition between wet markets and supermarkets, and among vendors 
within wet and wholesale markets, also contributes indirectly to reducing food costs and stabilizing food prices [66].

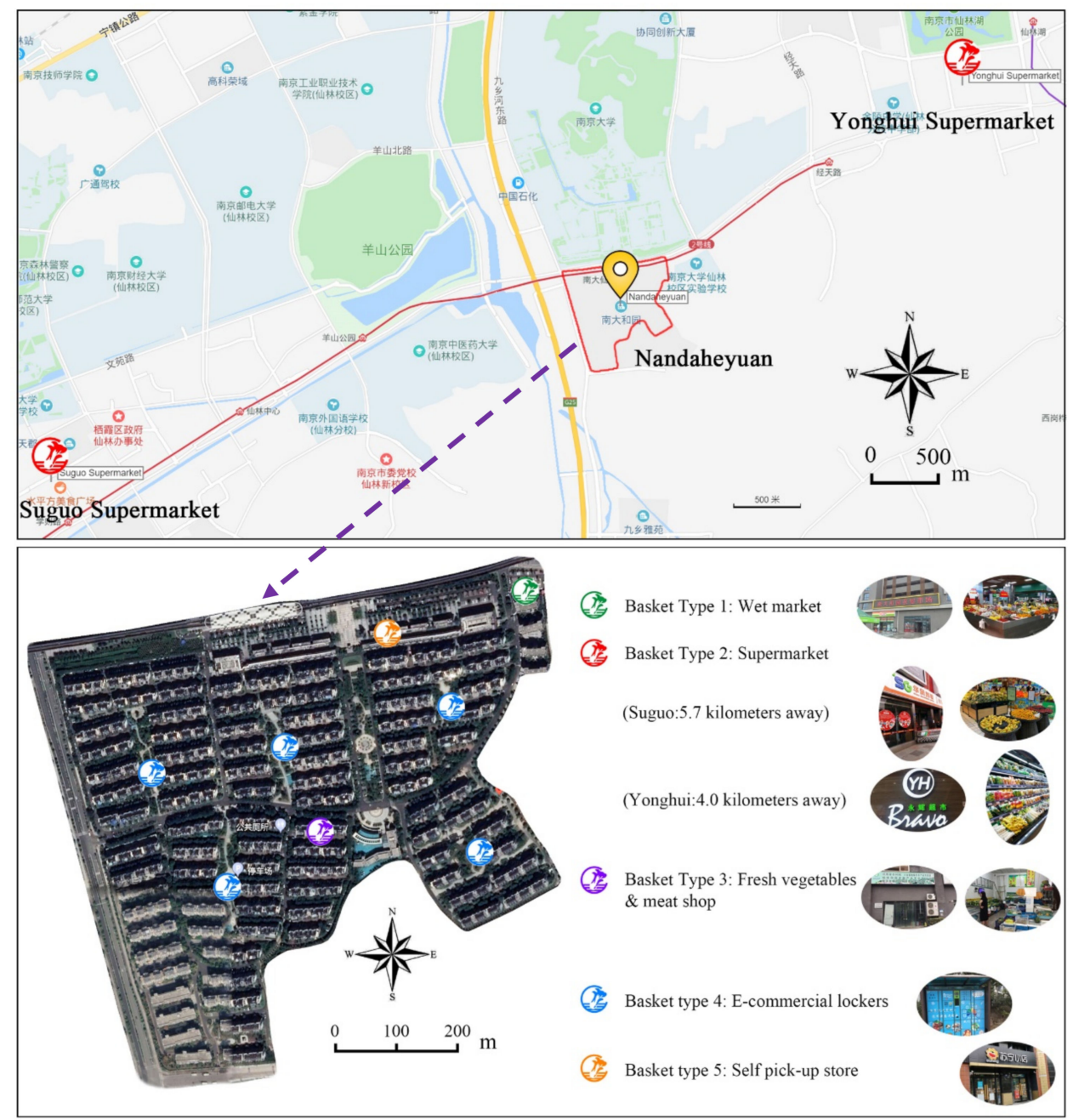

Figure 5. "Vegetable Baskets" plan for a neighbourhood in east Nanjing.

\subsection{Integrating Food Utilization}

Food safety has become a major concern of consumers throughout China [67]. In Nanjing, we found that three-quarters of surveyed household heads worry about the safety of their food on a daily basis $[65,68]$. Another recent study of narratives of sustainable consumption in Nanjing demonstrated similar deep-seated fears about contaminated food [69]. To try and allay consumer concerns about food safety, the Nanjing municipality has put several initiatives in place. First, the city is increasing the coverage of food production certification including pollution-free produce, green food, organic food, and geographical indication of agricultural products. Second, it is developing and improving the system of monitoring and testing of food safety and promoting food traceability. Third, to enhance the food purchase experience, it is promoting hygiene and upgrading of wet markets. Fourth, they called for intensified enforcement of food quality and safety regulations including building a food traceability system, establishing quick-test rooms in wet markets (for residue testing), and building organic vegetable production bases. Table 1 provides a summary of these food safety initiatives. 
Table 1. Food safety strategies in Nanjing plans. (Sources: Complied by authors).

\begin{tabular}{|c|c|c|c|}
\hline Item & 2008-2012 Plan & 2017 Plan & 2018 Plan \\
\hline Production & $\begin{array}{l}\text { Strengthening test system at } \\
\text { production place of vegetables. } \\
\text { Developing } 1333 \text { ha of } \\
\text { organic vegetables. } \\
\text { Promoting the system of Good } \\
\text { Agriculture Practice. }\end{array}$ & $\begin{array}{l}\text { Promoting certification of } \\
\text { pollution-free produce, green } \\
\text { food, organic food, and } \\
\text { geographical indication of } \\
\text { agricultural products. } \\
\text { Promoting ecological breeding. } \\
\text { Strengthening the supervision of } \\
\text { food quality at the source such as } \\
\text { monitoring agricultural input. }\end{array}$ & $\begin{array}{l}\text { The proportion of pollution-free } \\
\text { produce, green food, organic food, and } \\
\text { geographical indication of agricultural } \\
\text { products achieving more than } 55 \% \text {. } \\
\text { Subsidizing certification of } \\
\text { pollution-free produce, green food, } \\
\text { organic food, and geographical } \\
\text { indication of agricultural products. } \\
\text { Further promoting the system of Good } \\
\text { Agriculture Practice. }\end{array}$ \\
\hline Process & $\begin{array}{c}\text { Upgrading swine } \\
\text { slaughtering factory. } \\
\text { Implementing Quality Standard } \\
\text { management for meat } \\
\text { and poultry. }\end{array}$ & & \\
\hline Transaction & $\begin{array}{l}\text { Promoting the use of Integrated } \\
\text { Circuit Card transaction system. } \\
\text { Registration of food stall in } \\
\text { wet markets. } \\
\text { Upgrading } 40 \text { wet markets. }\end{array}$ & $\begin{array}{c}\text { Breeding local brand of } \\
\text { agricultural products. } \\
\text { Establish fast-test lab of food } \\
\text { safety in } 7 \text { food } \\
\text { wholesale markets. } \\
\text { Establish fast-test mini-lab of food } \\
\text { safety in } 80 \text { wet markets. } \\
\text { Upgrading wet markets. }\end{array}$ & $\begin{array}{l}\text { Further breeding local brand of } \\
\text { agricultural products. } \\
\text { Establish fast-test mini-lab of food } \\
\text { safety in } 100 \text { wet markets. } \\
\text { The coverage of traceability system for } \\
\text { meat, vegetable and fish achieving } \\
\text { 100\% of food wholesale markets, wet } \\
\text { markets and supermarkets within } \\
\text { urban area. } \\
\text { Upgrading } 101 \text { wet markets. }\end{array}$ \\
\hline Other & $\begin{array}{l}\text { Promoting the system of Hazard } \\
\text { Analysis Critical Control Points. } \\
\text { Developing produce } \\
\text { traceability system } \\
\text { Develop local series of standard } \\
\text { for food. }\end{array}$ & $\begin{array}{l}\text { Intensifying food quality } \\
\text { regulation enforcement. } \\
\text { Strengthening food quality } \\
\text { monitoring system. }\end{array}$ & $\begin{array}{l}\text { Implementing city-wide food quality } \\
\text { regulation enforcement. } \\
\text { Intensifying food quality supervision. } \\
\text { Improving the administration of } \\
\text { pesticides selling such as real name } \\
\text { registration system of pesticide buying. }\end{array}$ \\
\hline
\end{tabular}

\subsection{Addressing Multi-Level Food Stability Issues}

The final pillar of food security concerns stability of the food supply over time. A food reserve system and food supply emergency management were introduced in Nanjing in 2008 to cope with changes in weather conditions and economic factors that could jeopardize the stability of food security. The emergency management system includes food supply monitoring, an early warning mechanism, and releasing food reserves. When there is a shortage of food supply or a rise in food prices, stocks can be released onto the market. Comprehensive planning also incorporates both local and non-local food supplies, building a cooperation mechanism with other regions. For instance, the 2017 Plan encourages leading enterprises such as the Zhongcai Market Company (the biggest wholesale food market in Nanjing) to develop food production bases in regions outside of Nanjing through collaborating with other local governments. The Company provides production technology support to negotiate with the production base to get predictable prices. In addition, a consumer price subsidy policy was introduced, in which low-income households receive a food price subsidy if the CPI exceeds $3 \%$, which helps secure the stability of food access for low-income households.

\subsection{Other Food System Issues}

Although Nanjing has evolved a system of comprehensive food system planning and implementation, there are some elements of the food system with a bearing on food security that are not fully incorporated and are governed by alternative mechanisms 
and structures. The first of these concerns strategies to reduce food waste. Food waste management in China is largely separated from food system governance, although it has been a critical component of central regulations and policies such as the 12th and 13th FiveYear Plan. In recent years, several Chinese cities have started to formalize their food waste management system to foster the non-hazardous treatment and reuse of food waste [51,70]. In 2015, Nanjing has also developed a food waste management system including household recycling [71,72], but it has not been integrated into comprehensive food system planning.

The second issue that falls outside the ambit of comprehensive food system planning relates to public health and nutrition. A major gap in planning for food utilization is any explicit attempt to link it to public health and nutrition monitoring. "Vegetable basket" planning and public health and nutrition monitoring have both been developed in China since the end of the 1980s but barely interact with each other. A future more comprehensive plan for food and nutrition security and positive health outcomes would benefit from sharing information and resources between the two systems.

\section{Food Security Outcomes in Nanjing, China}

This section of the paper examines what comprehensive food system planning has meant for the food security of Nanjing residents in practice. In other words, has it achieved its overall goal of ensuring food security of the city's residents, and how does Nanjing compare in its food security outcomes with other large cities in the Global South?

In 2015-2017, the Hungry Cities Partnership implemented a standardized city-wide survey of household food security in seven different cities-Bangalore (India), Cape Town (South Africa), Kingston (Jamaica), Maputo (Mozambique), Mexico City (Mexico), Nanjing (China), and Nairobi (Kenya) [65,73-77]. The survey instrument included several cross-cultural standardized metrics for the assessment of food security: the Household Food Insecurity Access Scale (HFIAS), the Household Food Insecurity Access Prevalence (HFIAP) typology, the Household Dietary Diversity Score (HDDS), the Months of Adequate Household Food Provisioning score (MAHFP) and the Lived Poverty Index (LPI) [78-80]. The survey methodology and findings in Nanjing are discussed at greater length elsewhere [65].

Table 2 provides a comparative overview of the food security findings for the seven cities. On almost every metric, Nanjing had significantly better food security outcomes than the other cities. The HFIAS, for example, ranges from 0 (most food secure) to 27 (least food secure); the mean household score in Nanjing was only 0.6 compared with 3.2 in Mexico City, 5.8 in Nairobi and a high of 6.5 in Maputo and Kingston. On the HFIAP, $79 \%$ of Nanjing households were completely food secure and only $2 \%$ were severely food insecure. Comparable scores for severe food insecurity were $13 \%$ in Bangalore, $27 \%$ in Mexico City, and 36-38\% in Cape Town, Maputo and Kingston. On the HDDS, a measure of nutritional quality which scores each household from 0 to 12 , Nanjing had the best mean score (at 7.8) compared with 6.0 in Nairobi, 5.4 in Bangalore and a low of only 4.1 in Maputo. The MAHFP shows the number of months in the previous year that a household had "adequate" food (scored from 0 to 12). Nanjing had the highest mean at 12.0 and Windhoek and Cape Town the lowest (both less than 10). Finally, Nanjing had the lowest mean score on the LPI scale (which includes a question on food sufficiency).

Nanjing is the only one of these cities to have developed a comprehensive food system planning process although cities such as Nairobi and Cape Town have begun to move in this direction. While the Nanjing model is unlikely to be applicable in every detail in these other cities, there are certainly lessons to be drawn from several decades of food system planning in that city. Perhaps the most important lesson is that policies and plans aimed at mitigating food insecurity cannot simply focus on production and the availability of food, but need to take a more holistic approach that incorporates and plans for all four dimensions of food security. 
Table 2. Levels of household food security in HCP cities. (Source: Hungry Cities Partnership).

\begin{tabular}{llllllll}
\hline & Bangalore & Cape Town & Kingston & Maputo & $\begin{array}{l}\text { Mexico } \\
\text { City }\end{array}$ & Nairobi & Nanjing \\
\hline HFIAS (Mean) & 0.7 & 5.9 & 6.5 & 6.5 & 3.2 & 5.8 & 0.6 \\
HFIAP (\%) & & & & & & & \\
Food Secure & 83 & 46 & 26 & 29 & 50 & 29 & 79 \\
Mildly Food Insecure & 2 & 6 & 9 & 11 & 12 & 13 & 14 \\
Moderately Food Insecure & 2 & 13 & 28 & 22 & 11 & 33 & 5 \\
Severely Food Insecure & 13 & 36 & 37 & 38 & 27 & 25 & 2 \\
Mean HDDS & 5.4 & 6.8 & 4.5 & 4.1 & 5.9 & 6.0 & 7.8 \\
Mean MAHFP & 11.9 & 9.8 & 11.1 & 10.4 & 11.4 & 10.8 & 12.0 \\
Mean LPI & 0.23 & 0.65 & 0.47 & 0.53 & 0.27 & 0.46 & 0.10 \\
N & 1700 & 2500 & 702 & 2071 & 1200 & 1434 & 1210 \\
\hline
\end{tabular}

\section{Conclusions}

Using a case study from the city of Nanjing, this paper furthers our understanding of how Chinese urban food security has been planned in the context of rapid urbanization and food system transformation. In addition to Nanjing, food security planning has also been practiced in other Chinese cities including Shanghai, Guangzhou, Hangzhou and Fuzhou. The paper analyzes local government policy documents and plans, focusing primarily on how these policies changed and evolved over three decades to become increasingly comprehensive in scope. While the paper focuses primarily on policy development, it also examines the implementation of those policies in several areas using field survey data including an urban household food security survey in Nanjing and greenhouse farming data derived from remote-sensing images. By comparative standards, as the paper demonstrates in the final section, Nanjing has achieved a high degree of food security for the residents of the city. This is due, in no small measure, to the comprehensive planning approach adopted in the city. As local governments throughout the South seek to move beyond support for urban agriculture to more holistic food system planning, the Nanjing case offers some important guidance [10,22,81].

Long-term coordinated efforts by various international, national and local actors are obviously needed to begin to achieve the "Zero Hunger" target in the UN's 2030 Agenda for Sustainable Development. However, there is a very real danger that local urban actors including municipal governments-will be sidelined by the way in which the Agenda constructs the nature and remedies for global food insecurity [17]. As Battersby has argued, the SDG food goal has a flawed approach towards achieving food security because it neglects the urbanization of food insecurity [14]. Alcamo et al. point to another prescient challenge: the disconnect between national planning for SDGs and their implementation at the local scale [82]. SDGs aside, the double burden of malnutrition and food insecurity represent a growing crisis that largely falls on municipal governments to address and resolve. Here, there are three emerging governance perspectives on the "hidden linkages" between urbanization, food security and food systems in the Global South [83].

The first perspective comes out of initiatives supported by the UN and other agencies and is based on the premise that there are no substantive differences between cities in the North and the South and their food systems can therefore be governed in essentially the same way. Food system governance models developed in the North are thus easily and unproblematically transferable and applicable to the urban South. This view is best represented by the New Urban Agenda (NUA) of Habitat III, the FAO City-Region Food System (CFRS) program and the Milan Urban Food Policy Pact, all of which assume that the challenges of food system governance are essentially the same irrespective of geography. Critiques of the universalizing assumptions of these approaches are growing. Watson (2016), for example, argues that from a Southern planning perspective "extensive global difference in cities and regions renders universalized theorising and narrow conceptual models (especially in planning theory, given its relevance for practice) as invalid." 
A second perspective, best represented by the work of Gareth Haysom, is that the South needs to break with the North and ensure that food needs to become central to all facets of city governance and not ghettoized in particular departments, councils or urban agriculture programs $[10,84]$. That this is a highly ambitious project is amply demonstrated by the case of Cape Town. There the transformation of the food system is being driven by private sector interests who are taking advantage of the absence of any form of food system planning [85]. As Haysom also points out, and the SDGs are likely to reinforce, food security is a national not local mandate [10]. The example of Windhoek in Namibia is instructive here. Despite a whole array of national food security-related plans dating back to the 1990s, the specificity of the urban is unrecognized and the legislative and regulatory mandate of municipal governance ignores food governance almost entirely with the exception of a largely coercive but failing policy on the informal food sector [86].

A third perspective that the Southern city urban food system is sufficiently complex, distinctive, and dysfunctional in terms of food security outcomes to warrant the development and implementation of well-resourced and comprehensive food system planning at the municipal level. However, as Battersby and Watson (2019) note, work on food security has conventionally focused at either the household scale or at aggregate food production "with far less focus on the food system itself and its intersection with cities." Advocacy of a food systems approach to food governance in the South is certainly not new [87], but it has gained increasing traction, not least because there are good examples, such as Belo Horizonte in Brazil, of food system-based planning in action [60]. It is in this respect that the Chinese case in general, and the Nanjing case study in particular, becomes of particular interest and relevance under conditions of rapid urbanization [88].

Directives from and accountability to central government are a unique feature of the Chinese system, but how these national policies are interpreted and implemented locally leaves considerable room for municipal government to respond and to create its own context-specific governance structures and food system plans. As this paper shows, urban food system planning for food security in Nanjing has been incremental in nature but, over time, has sought to address all four of the classic pillars of food security. In addition, the city departments responsible for developing and implementing food planning have sought to address the challenges of food governance through a focus on the urban food system as a whole and its intersections with other aspects of urban planning and infrastructure. Incrementalism over time has been a central feature of Nanjing's food system planning case. Public health data that correlates with greater access to food over time would be invaluable in future research, particularly as increased access to unhealthy foods is fueling an increase in non-communicable disease in China, as elsewhere [89].

For Southern cities seeking to learn from the Nanjing experience, three decades of increasingly holistic planning is less important than the end-point of the process; that is, a multi-sectoral focus on the entire food system and how it is best governed to ensure the greatest benefit in terms of food security to the greatest number. The positive results of this planning process in Nanjing in terms of food security outcomes stand in stark contrast to other cities in the Global South for which there is comparable data. Even allowing for the specificity of Nanjing and China, Nanjing has used comprehensive planning as a tool for coordinating multiple agencies and the public and private sectors to achieve an extremely high level of food security. Merely integrating the food system into urban planning is not enough; comprehensive food system planning is urgently needed to address urban food security in the Global South.

Author Contributions: Conceptualization: T.Z., Z.S. and X.H.; formal analysis, T.Z., S.S., Z.S. and J.C.; investigation, T.Z. and Z.S.; data curation, T.Z. and K.Y.; writing-original draft preparation, T.Z., Z.S., S.S. and J.C.; writing—review and editing, J.C., T.Z., Z.S., S.S. and X.H.; supervision, J.C.; project administration, J.C.; funding acquisition, J.C. All authors have read and agreed to the published version of the manuscript. 
Funding: This research was funded by grants to the Hungry Cities Partnership by the Social Sciences and Research Council, grant numbers 895-2013-3005 and 895-2021-1004; and the International Development Research Centre, grant number 107775-001.

Institutional Review Board Statement: Collection of the Hungry Cities Partnership survey data presented in this paper was approved by the Ethics in Research Committee of the Faculty of Engineering and the Built Environment at University of Cape Town, South Africa; and the Ethics Review Board of the Office of Research Services, Wilfrid Laurier University, Canada.

Informed Consent Statement: Informed consent was obtained from all subjects involved in the study.

Data Availability Statement: Data is available from the authors on request.

Conflicts of Interest: The authors declare no conflict of interest.

\section{References}

1. Morgan, K. Feeding the City: The Challenge of Urban Food Planning. Int. Plan. Stud. 2009, 14, 341-358. [CrossRef]

2. Morgan, K. The Rise of Urban Food Planning. Int. Plan. Stud. 2013, 18, 1-4. [CrossRef]

3. Sonnino, R. Feeding the City: Towards a New Research and Planning Agenda. Int. Plan. Stud. 2009, 14, 425-435. [CrossRef]

4. Pothukuchi, K.; Kaufman, J. Placing the Food System on the Urban Agenda: The Role of Municipal Institutions in Food Systems Planning. Agric. Hum. Values 1999, 16, 213-224. [CrossRef]

5. Deakin, M.; Borrelli, N.; Diamantini, D. (Eds.) The Governance of City Food Systems: Case Studies from Around the World; Fondazione Feltrinelli: Milan, Italy, 2016.

6. De Amorim, W.; Deggau, A.; Goncalves, G.; Neiva, S.; Prasath, A.; de Andrade Guerra, J. Urban Challenges and Opportunities to Promote Sustainable Food Security Through Smart Cities and the 4th Industrial Revolution. Land Use Policy 2019, 87, 104065. [CrossRef]

7. Maye, D. 'Smart Food City': Conceptual Relations between Smart City Planning, Urban Food Systems and Innovation Theory. City Cult. Soc. 2019, 16, 18-24. [CrossRef]

8. Mendes, W.; Sonnino, R. Urban Food Governance in the Global North. In The SAGE Handbook of Nature; Sage: London, UK, 2018; pp. 543-560.

9. Sonnino, R. The New Geography of Food Security: Exploring the Potential of Urban Food Strategies. Geogr. J. 2016, 182, 190-200. [CrossRef]

10. Haysom, G. Perspectives on Urban Food System Governance in the Global South. In Handbook of Urban Food Security in the Global South; Crush, J., Frayne, B., Haysom, G., Eds.; Edward Elgar: Cheltenham, UK, 2020; pp. 363-379.

11. Watson, V. Locating Planning in the New Urban Agenda of the Urban Sustainable Development Goals. Plan. Theory 2018, 15, 435-438. [CrossRef]

12. MUFPP. Milan Urban Food Policy Pact. 2015. Available online: https://www.milanurbanfoodpolicypact.org/wp-content/ uploads/2020/12/Milan-Urban-Food-Policy-Pact-EN.pdf (accessed on 10 July 2021).

13. Blay-Palmer, A.; Santini, G.; Dubbeling, M.; Renting, H.; Taguchi, M.; Giordano, T. Validating the City Region Food System Approach: Enacting Inclusive, Transformational City Region Food Systems. Sustainability 2018, 10, 1680. [CrossRef]

14. Battersby, J. MDGs to SDGs-New Goals, Same Gaps: The Continued Absence of Urban Food Security in the Post-2015 Global Development Agenda. Afr. Geogr. Rev. 2017, 36, 115-129. [CrossRef]

15. Battersby, J.; Watson, V. The Planned 'City Region' in the New Urban Agenda: An Appropriate Framing for Urban Food Security? In Handbook on Urban Food Security in the Global South; Crush, J., Frayne, B., Haysom, G., Eds.; Edward Elgar: Cheltenham, UK, 2020; pp. 341-362.

16. Crush, J.; Frayne, B. Urban Food Insecurity and the New International Food Security Agenda. Dev. S. Afr. 2011, $28,527-544$. [CrossRef]

17. Crush, J.; Riley, L. Rural Bias and Urban Food Security. In Urban Food Systems Governance and Poverty in African Cities; Battersby, J., Watson, V., Eds.; Routledge: New York, NY, USA, 2019; pp. 42-55.

18. Binns, T.; Lynch, K. Feeding Africa's Growing Cities Into the 21st Century: The Potential of Urban Agriculture. J. Int. Dev. 1998, 10, 777-793. [CrossRef]

19. Redwood, M. (Ed.) Agriculture in Urban Planning: Generating Livelihoods and Food Security; Routledge: London, UK, 2008.

20. Zezza, A.; Tasciotti, L. Urban Agriculture, Poverty, and Food Security: Empirical Evidence from a Sample of Developing Countries. Food Pol. 2010, 35, 265-273. [CrossRef]

21. Haysom, G.; Tawodzera, G. 'Measurement Drives Diagnosis and Response': Gaps in Transferring Food Security Assessment to the Urban Scale. Food Policy 2018, 74, 117-125. [CrossRef]

22. Haysom, G. Food and the City: Urban Scale Food System Governance. Urban Forum 2015, 26, 263-281. [CrossRef]

23. Crush, J.; Frayne, B.; Haysom, G. (Eds.) Handbook on Urban Food Security in the Global South; Edward Elgar: Cheltenham, UK, 2020.

24. Qi, X.; Dang, H. Addressing the Dual Challenges of Food Security and Environmental Sustainability During Rural Livelihood Transitions in China. Land Use Pol. 2018, 77, 199-208. [CrossRef] 
25. Wang, J.; Zhang, Z.; Liu, Y. Spatial Shifts in Grain Production Increases in China and Implications for Food Security. Land Use Pol. 2018, 74, 204-213. [CrossRef]

26. UN. Sustainable Development Goals; United Nations: New York, NY, USA, 2016.

27. UN. The Millennium Development Goals Report 2015; United Nations: New York, NY, USA, 2015.

28. FAO. The State of Food Insecurity in the World 2015; FAO: Rome, Italy, 2015.

29. FAO. The State of Food Security and Nutrition in the World 2018; FAO: Rome, Italy, 2018.

30. FAO. The State of Food Security and Nutrition in the World 2020; FAO: Rome, Italy, 2020.

31. Du, J.; King, C. Unravelling China's Food Security Puzzle, 1979-2008. China Q. 2018, 235, 804-827. [CrossRef]

32. Ghose, B. Food Security and Food Self-Sufficiency in China: From Past to 2050. Food Ener. Secur. 2014, 3, 86-95. [CrossRef]

33. Lin, S. State Capitalism and Chinese Food Security Governance. Jpn. J. Pol. Sci. 2017, 18, 106-138. [CrossRef]

34. Zhang, H. Securing the 'Rice Bowl': China and Global Food Security; Palgrave Macmillan: London, UK, 2019.

35. Huang, J.; Yang, G. Understanding Recent Challenges and New Food Policy in China. Glob. Food Secur. 2017, 12, 119-126. [CrossRef]

36. Lang, G.; Miao, B. Food Security for China's Cities. Int. Plan. Stud. 2013, 18, 5-20. [CrossRef]

37. Chen, J. Rapid Urbanization in China: A Real Challenge to Soil Protection and Food Security. Catena 2007, 69, 1-15. [CrossRef]

38. Long, H.; Ge, D.; Zhang, Y.; Tu, S.; Qu, Y.; Ma, L. Changing Man-Land Interrelations in China's Farming Area Under Urbanization and its Implications for Food Security. J. Environ. Manag. 2018, 209, 440-451. [CrossRef]

39. Ge, D.; Long, H.; Zhang, Y.; Ma, L.; Li, T. Farmland Transition and Its Influences on Grain Production in China. Land Use Policy 2018, 70, 94-105. [CrossRef]

40. Ma, L.; Long, H.; Tu, S.; Zhang, Y.; Zheng, Y. Farmland Transition in China and its Policy Implications. Land Use Policy 2020, 92, 104470. [CrossRef]

41. Sheng, Y.; Song, L. Agricultural Production and Food Consumption in China: A Long-Term Projection. China Econ. Rev. 2019, 53, 15-29. [CrossRef]

42. Kendall, H.; Kuznesof, S.; Dean, M.; Chan, M.; Clark, B.; Home, R.; Zhong, Q.; Lui, C.; Brereton, P.; Frewer, L. Chinese Consumers' Attitudes, Perceptions and Behavioural Responses Towards Food Fraud. Food Control 2019, 95, 339-351. [CrossRef]

43. Lam, H.; Remais, J.; Fung, M.; Xu, L.; Sun, S. Food Supply and Food Safety Issues in China. Lancet 2013, 381, 2044-2053. [CrossRef]

44. Si, Z. Rebuilding Consumer Trust in Food: Community Supported Agriculture in China. In Sustainable Food Futures: Multidisciplinary Solutions; Duncan, J., Bailey, M., Eds.; Routledge: London, UK, 2017; pp. 34-45.

45. Wu, X.; Yang, D.; Chen, L. The Politics of Quality-of-Life Issues: Food Safety and Political Trust in China. J. Contemp. China 2017, 26, 601-615. [CrossRef]

46. Crush, J. Approaching Food Security in Cities of the Global South. In Routledge Handbook on Cities of the Global South; Parnell, S., Oldfield, S., Eds.; Routledge: London, UK, 2014; pp. 543-555.

47. Crush, J.; Battersby, J. (Eds.) Rapid Urbanisation, Urban Food Deserts and Food Security in Africa; Springer: Dordrecht, The Netherlands, 2016.

48. Tacoli, C. Food (In) Security in Rapidly Urbanizing, Low-Income Contexts. In Handbook of Urban Food Security in the Global South; Crush, J., Frayne, B., Haysom, G., Eds.; Edward Elgar: Cheltenham, UK, 2020; pp. 23-34.

49. Ruel, M.; Leroy, J.; Ecker, O.; Hernandez, M.; Resnick, D.; Thurlow, D. Urban Food Systems and Diets, Nutrition and Health of the Poor: Challenges, Opportunities, and Research Gaps. In Handbook of Urban Food Security in the Global South; Crush, J., Frayne, B., Haysom, G., Eds.; Edward Elgar: Cheltenham, UK, 2020; pp. 380-396.

50. Zhang, J.; Zhang, C.; Sustainability Insights: Shanghai's Food Waste Management. Collect. Responsib. 2018. Available online: https:/ / www.coresponsibility.com/wp-content/uploads/2018/11/Shanghai-China-Food-Waste-Management-Report.pdf (accessed on 6 August 2021).

51. Pothukuchi, K.; Kaufman, J. The Food System: A Stranger to the Planning World. J. Am. Plan. Assoc. 2000, 66, 113-124. [CrossRef]

52. Morgan, K. Nourishing the City: The Rise of the Urban Food Question in the Global North. Urban Stud. 2015, 52, 1379-1394. [CrossRef]

53. Battersby, J.; Watson, V. (Eds.) Urban Food Systems Governance and Poverty in African Cities; Routledge: New York, NY, USA, 2019.

54. Ministry of Agriculture. Rules for Implementation of the Measures for Evaluating the Performance of City Mayors Responsible for Non-Grain Food Supply. 2017. Available online: http:/ /www.moa.gov.cn/nybgb/2017/dsanq/201712/t20171228_6133439.htm (accessed on 22 February 2020).

55. Command Office of the Vegetable Basket Project in Nanjing. The Vegetable Basket Project in Nanjing; Internal Government Document Collection: Nanjing, China, 2001.

56. Nanjing Government. The Vegetable Basket Project Planning for Nanjing (2008-2012). Nanjing People's Gov. Bull. 2009, 1, 6-20.

57. Nanjing Government. The Notification of Key Tasks for the Vegetable Basket Project in Nanjing in 2017. 2017. Available online: http:/ / www.nanjing.gov.cn/zdgk/201810/t20181022_573608.html (accessed on 19 February 2019).

58. Nanjing Government. The Notification of Key Tasks for the Vegetable Basket Project in Nanjing in 2018. 2018. Available online: http:/ / www.njdaily.cn/2018/0627/1708139.shtml (accessed on 20 February 2019).

59. Rocha, L.; Less, I. Urban Governance for Food Security: The Alternative Food System in Belo Horizonte, Brazil. Int. Plan. Stud. 2009, 14, 389-400. [CrossRef] 
60. Zhong, T.; Si, Z.; Shi, L.; Ma, L.; Liu, S. Impact of State-Led Food Localization on Suburban Districts' Farmland Use Transformation: Greenhouse Farming Expansion in Nanjing City Region, China. Landsc. Urban Plan. 2020, 202, 103872. [CrossRef]

61. Dolley, J.; Marshall, F.; Butcher, B.; Reffin, J.; Robinson, J.A.; Eray, B.; Quadrianto, N. Analysing Trade-offs and Synergies between SDGs for Urban Development, Food Security and Poverty Alleviation in Rapidly Changing Peri-urban Areas: A Tool to Support Inclusive Urban Planning. Sustain. Sci. 2020, 15, 1601-1619. [CrossRef]

62. NMBS. Bulletin of the Main Data of the Third National Agricultural Census in Nanjing; Nanjing Municipal Bureau of Statistics: Nanjing, China, 2018. Available online: http:/ / tjj.nanjing.gov.cn/njstjj/201810/t20181021_527769.html (accessed on 17 December 2019).

63. Yuan, Y.; Si, Z.; Zhong, T.; Huang, X.; Crush, J. Revisiting China's Supermarket Revolution: Complementarity and Co-evolution Between Traditional and Modern fFood Outlets. World Dev. 2021, 147, 105631. [CrossRef]

64. Si, Z.; Zhong, T. The State of Household Food Security in Nanjing, China; HCP Report No. 9; Hungry Cities Partnership: Waterloo, ON, Canada; Cape Town, South Africa, 2018.

65. Zhong, T.; Si, Z.; Crush, J.; Scott, S.; Huang, X. Achieving Urban Food Security through a Hybrid Public-Private Food Provisioning System: The Case of Nanjing, China. Food Secur. 2019, 11, 1071-1086. [CrossRef]

66. Wu, Y.; Xi, X.; Tang, X.; Luo, D.; Gu, B.; Lam, S.; Vitousek, P.; Chen, D. Policy Distortions, Farm Size, and the Overuse of Agricultural Chemicals in China. Proc. Natl. Acad. Sci. USA 2018, 115, 7010-7015. [CrossRef]

67. Si, Z.; Regnier-Davies, J.; Scott, S. Food Safety in Urban China: Perceptions and Coping Strategies of Residents in Nanjing. China Inf. 2018, 32, 377-399. [CrossRef]

68. Liu, C.; Valentine, G.; Venderbeck, M.; McQuaid, K.; Diprose, K. Placing 'Sustainability' in Context: Narratives of Sustainable Consumption in Nanjing, China. Soc. Cult. Geogr. 2019, 20, 1307-1324. [CrossRef]

69. Freese, L.; Han, S. From Farm to Table to Energy: Co-Digesting China's Urban Food Waste in Wastewater Treatment Plants. 2019. Available online: https:/ / www.globalmethane.org/documents/406715866-From-Farm-to-Table-to-Energy-Co-digesting-Chinas-Urban-Food-Waste-in-Wastewater-Treatment-Plants.pdf (accessed on 6 August 2021).

70. Li, C.; Huang, Y.; Harder, M. Incentives for Food Waste Diversion: Exploration of a Long Term Successful Chinese City Residential Scheme. J. Clean. Prod. 2017, 156, 491-499. [CrossRef]

71. Nanjing Government. The Management Strategy of Kitchen Waste in Nanjing. 2015. Available online: http:/ / www.nanjing.gov cn/zdgk/201605/t20160510_1056908.html (accessed on 6 August 2021).

72. Koduganti, J.; Adelina, C.; Mohanraju, J.; Anand, S. The State of Household Food Security in Bangalore, India; HCP Report No. 14; Hungry Cities Partnership: Waterloo, ON, Canada; Cape Town, South Africa, 2019.

73. Crush, J.; Caesar, M.; Haysom, G. The State of Household Food Security in Cape Town, South Africa; HCP Report No. 12; Hungry Cities Partnership: Waterloo, ON, Canada; Cape Town, South Africa, 2018.

74. Thomas-Hope, E.; Kinlocke, R.; Timmers, B. The State of Household Food Security in Kingston, Jamaica; HCP Report No. 15; Hungry Cities Partnership: Waterloo, ON, Canada; Cape Town, South Africa, 2019.

75. Raimundo, I.; McCordic, C.; Chikanda, A. The State of Household Food Security in Maputo, Mozambique; HCP Report No. 10; Wilfrid Laurier University: Waterloo, ON, Canada; University of Cape Town: Cape Town, South Africa, 2018.

76. Capron, G.; Arellano, S.; Wagner, J.; McCordic, C. The State of Household Food Security in Mexico City, Mexico; HCP Report No. 1; Wilfrid Laurier University: Waterloo, ON, Canada; University of Cape Town: Cape Town, South Africa, 2018.

77. Owuor, S. The State of Household Food Security in Nairobi, Kenya; HCP Report No. 11; Wilfrid Laurier University: Waterloo, ON, Canada; University of Cape Town: Cape Town, South Africa, 2018.

78. Bilinsky, P.; Swindale, A. Months of Adequate Household Food Provisioning (MAHFP) for Measurement of Household Food Access: Indicator Guide; Version 4; FHI 360/FANTA: Washington, DC, USA, 2010.

79. Coates, J.; Swindale, A.; Bilinsky, P. Household Food Insecurity Access Scale (HFIAS) for Measurement of Household Food Access: Indicator Guide; Version 3; FHI 360/FANTA: Washington, DC, USA, 2007.

80. Swindale, A.; Bilinsky, P. Household Dietary Diversity Score (HDDS) for Measurement of Household Food Access: Indicator Guide; Version 2; FHI 360/FANTA: Washington, DC, USA, 2006.

81. Watson, V. Shifting Approaches to Planning Theory: Global North and South. Urban Plan. 2016, 1, 32-41. [CrossRef]

82. Alcamo, J.; Thompson, J.; Alexander, A.; Antoniades, A.; Delabre, I.; Dolley, J.; Matshall, F.; Menton, M.; Middleton, J.; Scharlemann, J. Analysing Interactions Among the Sustainable Development Goals: Findings and Emerging Issues from Local and Global Studies. Sustain. Sci. 2020, 15, 1561-1572. [CrossRef]

83. Seto, K.; Ramankutty, N. Hidden Linkages between Urbanization and Food Systems. Science 2016, 352, 943-945. [CrossRef] [PubMed]

84. Haysom, G. Integrating Food Sensitive Planning and Urban Design into Urban Governance Actions. Urban Forum 2021, 32, 289-310. [CrossRef]

85. Battersby, J. Food System Transformation in the Absence of Food System Planning: The Case of Supermarket and Shopping Mall Retail Expansion in Cape Town, South Africa. Built Environ. 2017, 43, 417-430. [CrossRef]

86. Crush, J.; Nickanor, N.; Kazembe, L. Urban Food System Governance and Food Security in Namibia; HCP Discussion Paper No. 49; Hungry Cities Partnership: Waterloo, ON, Canada; Cape Town, South Africa, 2020. 
87. Smith, D. Urban Food Systems and the Poor in Developing Countries. Trans. Inst. Br. Geogr. 1998, 23, 207-219. [CrossRef]

88. Wang, Y. The Challenges and Strategies of Food Security under Rapid Urbanization in China. Sustainability $2019,11,542$. [CrossRef]

89. Wu, F.; Narimatsu, H.; Li, X.; Nakamura, S.; Sho, R.; Zhao, G.; Nakata, Y.; Xu, W. Non-Communicable Disease Control in China and Japan. Glob. Health 2017, 13, 91. [CrossRef] [PubMed] 